\title{
The Presumption of Legitimacy Under Section 165 of the Evidence Act and Its Inadequacies in the Determination of Legitimacy Status/Paternity of a Child: A Call for the Adoption of Genetic Testing (DNA Test) as a Preferable and Conclusive Proof of Paternity
}

\author{
Ani, Chijioke Collins \\ BSc, LLB, B.L, LLM, PGDE, Law Teacher, Department of Business Law, Faculty of Law, Enugu State \\ University of Science and Technology, Enugu, Nigeria. \\ Chime, Onyinye Hope \\ MBBS, MPH, FWACP, Consultant Physician, Lecturer, Department of Community Medicine, Enugu State \\ University College of Medicine, Enugu, Nigeria.
}

\begin{abstract}
The Presumption of Legitimacy Under Section 165 of the Evidence Act and its Inadequacies in the Determination of Legitimacy Status/Paternity of a Child: A Call for the Adoption of Genetic Testing (DNA Test) as a Preferable and Conclusive Proof of Paternity.

Abstract

The Nigerian Courts in plethora of cases have placed heavy reliance on the presumption provided for under Section 165 of the Evidence Act in the determination of the paternity/legitimacy status of a child. This rebuttable presumption clothes the court with the power to make certain inferences as to the paternity of a child once it is established that such a child was given birth to during the subsistence of a valid marriage. The Court can also in situations where the marriage has been dissolved also make the same inferences, if the child was given birth to within the permitted gestation period. This rebuttable presumption provided for under Section 165 of the Evidence Act also presupposes that where a married woman in the course of an extramarital affair gets pregnant and such pregnancy is accepted by the husband, if any claim by a third party is made in respect of such child, the Court is clothed with the power under the Act to presume that the product of such extramarital affair is a legitimate child of the subsisting valid marriage. This paper, in the face of technological advancements in genetic testing which involves DNA Profiling, contends and argues that the presumption provided for under Section 165 of the Evidence Act is grossly inadequate in the determination of paternity of a child most especially where the paternity of such child is in dispute.
\end{abstract}

Keywords: Paternity, Marriage, Legitimacy, Presumption, Gestation Period, DNA, Genetic.

DOI: $10.7176 / \mathrm{JLPG} / 111-08$

Publication date:July $31^{\text {st }} 2021$

\subsection{Introduction}

Considering the patrilineal nature of the Nigerian milieu and the stigma associated with the illegitimacy status of a person, it is imperative that a more precise mode of ascertaining paternity should be adopted. While so many persons have been disentitled from their inheritance on basis of failure to prove that they were born during the subsistence of a valid marriage, so many marriages have either broken down or have experienced turbulence and chaos due to paternity fraud. So many husbands have laboured and toiled in raising children of another under the misconceived presumption that any child born during the subsistence of a valid marriage is deemed a child of the man. Under the Evidence Act, ${ }^{1}$ once a child is born during the subsistence of a valid marriage, there is a presumption that the child belongs to the husband of the woman and thus a legitimate child. This presumption of law is a strong legal presumption on the ground that public policy favours legitimacy to preserve stable family groupings. This presumption of law as contained in Section 165 of the Evidence Act reads thus:

Without prejudice to Section 84 of the Matrimonial Cause Act, ${ }^{2}$ where a person was born during the continuance of a valid marriage between his mother and any man or within 280 days after dissolution of the marriage, the mother remaining unmarried, the Court shall presume that the person in question is the legitimate child of that man.

This presumption is however rebuttable if there is evidence suggesting that at the time conception ought to

\footnotetext{
${ }^{1} 2011$, Section 165.

${ }^{2}$ Cap. M7 LFN 2004, the said Section 84 provides that notwithstanding any rule of law in proceeding under this Act either party to a marriage may give evidence proving or tending to prove that the parties to the marriage did not have sexual relations with each other at any particular time, but shall not be compellable to give such evidence if it would show or tend to show that a child born to the wife during this marriage was illegitimate.
} 
have taken place, the man did not have sexual intercourse with the woman or that the man was away from his matrimonial home. Thus, a child born to a married couple is presumed to be their legitimate offspring in the absence of a clear demonstration that the husband could not possibly be the father. For instance, a man who slipped into coma for a period of over 490 days, ${ }^{1}$ cannot be said to be the father of a child born 4 or 5 days after he regained consciousness. Relatedly, a soldier who was on official duty for a continuous period of two years in a distant country could not have had access to his wife to have sexual intercourse hence any child born within ten days upon his arrival cannot be said to be the child of the man. Although this presumption is rebuttable, the line of reasoning adopted by the courts has shown that the evidence for the purpose of repelling the presumption must be strong, distinct, satisfactory and conclusive. ${ }^{2}$ Reiterating the foregoing principle, the Supreme Court in Elumeze v. Elumeze ${ }^{3}$ opined that anyone born by the wife of a valid marriage is presumed legitimate, unless it can be proved that the husband and wife had no access to each other or that sexual intercourse could not have taken place.

\subsection{Presumption of Legitimacy under the Evidence Act and its limitations}

As earlier stated, a child is legitimate if born during the pendency of a valid marriage. The marriage referred to as being valid, includes both marriage under the Act, Customary marriage and Islamic marriage. The only thing expected from the party who is relying on the existence of a valid marriage to prove his paternity is to show that he was born during the subsistence of the valid marriage. In a situation where the valid marriage was dissolved before the delivery of the child, what is expected to prove is that the child was born within the permitted period of gestation. The burden of proof lies on the party relying on the fact that the child was born during the subsistence of a valid marriage or within the permitted gestation period. However, where the husband/father of the child is the party denying paternity, the onus lies on him to prove that at the time conception was assumed to have taken place he was away from his wife or that it was practically impossible that he could have had sexual intercourse with his wife. In the absence of such cogent and credible evidence, it is presumed in law that the child is legitimate and belongs to the man. ${ }^{4}$ According to Aguda, ${ }^{5}$ even where the wife commits adultery, Customary Courts nevertheless invariably rules in favour of the legitimacy of the child especially where the lawful husband of the woman subsequently acknowledges the child as his. In Idahosa v. Idahosa \& Ors., ${ }^{6}$ upon the death of their father (Pa Idahosa) and mother (Madam Onaiwu) of the Appellant \& $1^{\text {st }}$ Respondent (who are brothers), the $1^{\text {st }}$ Respondent reported an alleged dying confession of their mother; that the Appellant was not sired by their father rather by one Pa Osayande. Thus, the Appellant was illegitimate and consequently could not inherit the Igiogbe. The trial Court found for the Respondent but on appeal the decision was set aside. This strong presumption of legitimacy was demonstrated by the Court of Appeal in this case when it rejected the evidence given by DW2 (Pa Osayande) that he knew the mother of the Appellant and $1^{\text {st }}$ Respondent and that in course of his relationship with the mother (Madam Onaiwu) of the Appellant \& $1^{\text {st }}$ Respondent, the Appellant and his older sister were born. The Court held that there is no doubt that the Appellant and his older sister were born during the continuance and subsistence of some form of a lawful and valid marital union recognized by law between Late Madam Onaiwu and Late $\mathrm{Pa}$ Idahosa. In the absence of any evidence that during their life time, Pa Idahosa had any doubts about the paternity of the Appellant and his older sister, the paternity of the Appellant and his older sister is a matter within their exclusive knowledge. The Court rejected the evidence of Pa Osayande (DW2) as fanciful or deluded ideas and thoughts of a senile blind man who was at the sunset of life. ${ }^{8}$ The said decision on appeal was also affirmed by the Supreme Court. ${ }^{9}$ Also in Anozie v. Uwakwe, ${ }^{10}$ the Appellant's claim for ownership of the foetus in the womb of the Respondent; a married woman on ground that he had sexual intercourse with the woman was out rightly rejected by the Court of Appeal as a wishful fantasy and wild speculation. The Court stated that in absence of a state of marriage between the Appellant and the woman, he cannot lay such claim to the foetus; more so when the married woman has denied his paternity to the foetus.

While the decision reached in the Idahosa case was partly influenced by the fact that there was no evidence to show that the husband of the marriage (Pa Idahosa) ever doubted the paternity of the Appellant and $1^{\text {st }}$ Respondent, the Court of Appeal's decision in Anozie's case was also influenced by the denial raised by the

\footnotetext{
${ }^{1}$ The average length of human gestation is 280 days or 40 weeks from the first day of the woman's menstrual period.

${ }^{2}$ See C.C Ani, Understanding Legal Concepts in Nigeria, Volume II (Enugu: CIDJAP,2020) P.81.

See also Piers v. Piers (1894) 9 ER 1132.

${ }^{3}$ (1969) LPELR-25522 (SC); (1969) 1 ANLR 301.

${ }^{4}$ L., Atsegbua, Law of Evidence (Benin-City: Justice Jeco Printing \& Publishing Global, 2012) p. 248.

${ }^{5}$ A., Aguda, The Law of Evidence Reprint (Ibadan: Spectrum Books Ltd,2007) p.253.

${ }^{6}$ (2010) LPELR-9072 (CA).

${ }^{7}$ Under the Benin native custom, the eldest surviving male child of a man is entitled under the custom to inherit the house the man lived and died commonly called the Igiogbe.

${ }^{8}$ See Idahosa v. Idahosa \& Ors. Supra (n.8) at p. 42, paras. E, Per Gumel, JCA. There was no evidence that DW2 (Pa Osayande) ever confronted Madam Onaiwu with any evidence he ever had if any at all, of his paternity of two of her children.

${ }^{9}$ See Idahosa v. Idahosa (2020) 6 NWLR (Pt.1720) 254 SC.

${ }^{10}$ (2016) LPELR-4055 (CA).
} 
married woman. The foregoing judicial decisions is a pointer that the onus to rebut this presumption of legitimacy by evidence most times lies with either the father or mother of the child whose status is in contention and there is no compulsion to give such evidence if it will show that the child born during the marriage is illegitimate. ${ }^{1}$ Thus an impotent husband upon an agreement with his wife may lure an unsuspecting male to impregnate his wife and then find succor and protection under section 165 of the Evidence Act. It can therefore be said that the unsuspecting male will definitely face an ordeal of proving that the child belongs to him if a strict reliance is made on the legal presumption in the determination of the paternity of the child, most especially where the couple are at accord to conceal certain facts surrounding the conception of the child which was as a result of the extramarital affair.

Furthermore, this presumption of law, if relied on strictly, may create a difficult state for a wife of an impotent husband to discharge the evidential burden imposed on her in proving that the children of the marriage belongs to someone else and not the impotent husband. In Oduche v. Oduche, ${ }^{2}$ the contention of a woman (Appellant) that her husband (Respondent) was not the father of the children of the marriage on grounds of impotency of her husband was rejected by the Court in view of the fact that it was common ground that during the subsistence of the marriage, both parties had sexual intercourse. Dismissing the appeal, the Court of Appeal penned thus:

There is no burden on the Respondent to call a witness to establish the fact that he is capable of impregnating his wife. The law presumes the fact. Indeed, when a child is born in a valid marriage. The law presumes that the married couple had sexual intercourse between themselves. I am satisfied that the trial judge was right in his findings that the three children are indeed the children of the Respondent. The Appellant being unable to rebut the presumption in $\mathrm{S} 48$ of the Evidence Act. $^{3}$

The husband of a valid marriage is also not left out from the hardship caused by a strict application of this legal presumption in the resolution of paternity when in dispute. For instance, a suspicious husband who is in doubt of the paternity of the products of the marriage may find it quite impossible to prove the paternity of the products of the marriage most especially where the couple was sexually active during the supposed time of conception. The snag that might be faced by such husband comes into play where the Court in the resolution of the paternity in dispute, decides to jettison genetic testing (DNA test) and instead relies on the legal presumption that any child of a valid marriage is deemed a legitimate child of the marriage.

In Ibeabuchi v. Ibeabuchi, ${ }^{4}$ the denial by the Appellant (husband) of the paternity of a child (Anointed Ibeabuchi) born by the Respondent (wife) during the subsistence of their marriage was rejected by the Court of Appeal. According to the Appellant, the Respondent claimed to be pregnant in May, 2005 and gave birth on $15^{\text {th }}$ December, 2005 hence it was impossible for Anointed Ibeabuchi to have been conceived and born within a period of 6-7 months. The Court applied the presumption of legitimacy provided for by S 165 of the Evidence Act and held thus:

On the totality of evidence adduced by the Appellant and the balance of probability. The learned trial judge of the Lower Court was right when he held in page 359 of the record that Master Annointed Ibeabuchi was born during the subsistence of the valid marriage between the Appellant and the Respondent. ${ }^{5}$

Also in the Islamic case of Rabiu v. Amadu, ${ }^{6}$ the principal issue involved in the case was hinged on the conviction that the child delivered by the Respondent was given birth to within a period below the minimum permissible gestation period allowed under Islamic Law. The facts of the case are that the Appellant married the Respondent on 29/12/1990. They stayed together from 03/01/1991 when the Respondent moved in until 15/02/1991 when the Appellant brought her back to her parents over the dispute arising from her pregnancy. The pregnancy was found out within the 42 days they cohabitated which is $03 / 01 / 1991$ to $15 / 09 / 1991$, thus, the pregnancy of the Respondent was discovered during or within the period when the Respondent was lawfully and validly married to the Appellant. Dismissing the appeal of the Appellant denying the pregnancy of the Respondent, the Court held that under Sharia, a child conceived in lawful and valid wedlock is a legitimate child of a man so lawfully and validly married to its mother. This is because under Sharia, the legitimacy of a child is proved by the proof of the existence of a lawful and valid marriage between the parents at the time of the child's conception. In the same case, the Court laid down situations under Islamic Law, where paternity is presumed as the following:

\footnotetext{
${ }^{1} \mathrm{~S} 84$, Matrimonial Causes Act, Cap. M7, Laws of Federation of Nigeria, 2004.

2 (2005) LPELR-5976 (CA); (2006) 2 FWLR (Pt. 310) 2255; (2006) 5 NWLR (Pt. 972) 102.

${ }^{3}$ See Oduche v Oduche Supra. (n.14) at p. 10-11, paras. F-C, Per Rhodes-Vivour, JCA (as he then was). S 148 of the Evidence Act being referred to is the extant S 165 of Evidence Act, 2011.

4 (2016) LPELR-41268 (CA)

${ }^{5}$ Ibid. at p. 16, paras. E-G, Per Bdliya, JCA.

${ }^{6}$ (2002) LPELR-9161 (CA); (2003) 5 NWLR (Pt. 813) 343.
} 
(i) Where marriage contract exists between the spouses either de jure or de facto.

(ii) Where there is actual consummation or possibility of consummation between the Spouse without hindrance.

(iii) Where the child is born within the minimum or maximum period of gestation. ${ }^{1}$

(iv) Where there is no legal denial (LIAN: Mutual Imprecation) by the spouses. ${ }^{2}$

There may also be situations where a child or children have hinged their right to succession on the basis that they are products of a valid marriage so as to enable them partake in the partitioning of the estate of their late father. Such children are expected to show by cogent evidence that at the time of conception and birth, their mother was validly married to their father and in a situation where they fail to adduce any cogent evidence, they may be excluded in the partitioning of the estate. This paper contends that in the absence of any cogent evidence that the children were products of a valid marriage or that they were acknowledged during the lifetime of their father, it may cause untold hardship to these children if a more accurate mode of ascertaining paternity like DNA testing is rejected by both the trial and appellate Courts. In Okolonwamu v. Okolonwamu, ${ }^{3}$ the Appellants were faced with an arduous task of proving that the testator validly married their mother under Asaba Native Law and failing to do so their claim on paternity based on existing marriage failed on the ground that marriage of the said parents must first be proved before paternity can be presumed. In Jatau v. Mailafiya ${ }^{4}$ which was decided based on Islamic Law, the Supreme Court endorsing the legal presumption opined thus :

A child's paternity or affinity is not considered through physical resemblance but by consideration of the period which the child is born after consummation of the marriage of his parents. The consensus of opinion in the Maliki School is that if a child is born within 6 months of consummation of the marriage the child is affiliated to the husband. ${ }^{5}$

\subsection{Other Judicially Noted Modes of Proving Paternity}

In light of the limitations associated with the legal presumption as discussed above, there are other methods for proving the paternity of a child. The Court of Appeal in Okolonwamu \& Anor. v. Okolonwanu \& Ors. ${ }^{6}$ laid down ways by which paternity can be proved in the following words:

1.Paternity by existing marriage: A child born during the pendency of a valid marriage between a couples is automatically presumed to be legitimate. 2. Paternity by subsequent marriage to the mother: This occurs when a child is born at a time when the mother was not married to the father and after whose birth the mother and father entered into a valid marriage. 3.Paternity by acknowledgement by the father accepting paternity of the child: This incudes paying for the hospital bills and upkeep of the child, introducing the child to his family as his child etc. ${ }^{7}$

\subsection{Proof by Subsequent Marriage}

S 3(1) of the legitimacy Act of $1929^{8}$ is instructive on this. The said legislation provides thus:

Where the parents of an illegitimate person marry one another whether before or after the commencement of this Act, the marriage shall if the father of the illegitimate person was or is at the date of the marriage domiciled in Nigeria render that person if living legitimate from the commencement of this Act, or from the date of the marriage whichever happens.

This is also a form of legitimation. Legitimation can be defined as a process whereby an illegitimate child is made legitimate. Legitimation presumes that the child is legitimate. Some of the salient conditions to be fulfilled under the foregoing S 3(1) of the Legitimacy Act are:

(i) It is in respect of marriage celebrated under the Act. ${ }^{9}$

(ii) The father of the illegitimate person must be domiciled in a State in Nigeria at the time of the marriage.

(iii) The parents of the illegitimate person must have subsequently married each other validly under the Marriage Act.

\footnotetext{
${ }^{1}$ Under the Evidence Act, the permitted period of gestation for the presumption of paternity is 280 days while under Islamic Law, the minimum period is six months while maximum is five years. See also Tanimu v. Kura (2017) LPELR-43097 (CA).

${ }^{2}$ See Abdusalami Ustaz v. Jamila Abdullahi (2015) LPELR-40740 (CA).

${ }^{3}$ (2014) LPELR-22631 (CA). See also Masama v. Magama (2018) LPELR-46486 (CA) where the Court of Appeal held that in the absence of proof of a valid marriage, the lower trial Court was wrong to have attributed paternity to the Appellant on the basis of presumption of law. ${ }^{4}$ (1998) LPELR-1598 (SC).

${ }^{5}$ See Jatau v. Mailafiya Supra. (n.22). at p. 10 - 11, paras. F-A, Per Mohammed, JSC.

${ }^{6}$ Supra. (n.21).

${ }^{7}$ Ibid at p. 43-44, para. C, Per Ogunwimuju JCA.

${ }^{8}$ Ordinance No 27 of 1929

${ }^{9}$ M.O, Izzi, C.D, Longjohn, 'An Analysis of Concepts of Legitimacy and Legitimation Under Nigerian Family law', Journal of Property Law and Contemporary Issues, 20175 (1), p. 187.
} 
(iv) The illegitimate person to be legitimated must be living at the time of the marriage.

It is pertinent to note that nothing precludes an illegitimate person from being legitimated under Customary Law by subsequent marriage of both parents, provided that none of the parents at the time of such subsequent marriage is legally married to another person by virtue of a marriage celebrated under the Act. This prohibition is in respect of statutory marriages only because many if not all Customary Law permits polygamy. However, this prohibition can also come into play under Customary Law where the mother of the child at the time of the subsequent marriage is validly married to another under Customary Law. It then follows that for the fact that the putative father was legally married to a person under Customary Law at the time of the subsequent marriage will not affect the process of legitimation by subsequent marriage based on the fact that most Customary Law permits polygamy. The consequence of legitimation by subsequent marriage under the Legitimacy Act is that such a person has the same rights and is under the same obligation in respect of maintenance and support for himself or any other person as if he had been born legitimate. ${ }^{1}$ Such a person, his wife and children are also enabled by such legitimation to take as from the date of legitimation, interest in property or intestacy or disposition occurring after the date of the legitimation as if he had been born legitimate. ${ }^{2}$ In the determination of seniority in respect to distribution of property, the legitimated person ranks as if he had been born on the date when he became legitimated. If however, there are more persons who were legitimated at the same time, they will rank inter se in their natural order of seniority. ${ }^{3}$

\subsection{Proof by Acknowledgement}

Acknowledgement occurs where the putative father of a person recognizes and accepts (expressly or by conduct) paternity of such person. Acknowledgment can also occur in absence of any valid marriage between the putative father with his paramour. ${ }^{4}$ Acknowledgement is one of the accepted ways of legitimizing an illegitimate child and at the same time a mode of proving paternity of an illegitimate child. Prior to the coming into force of S 39(2) of the 1979 Constitution, ${ }^{5}$ there have been divergent and conflicting views on decency and propriety of acknowledging children born outside wedlock so as to give them the same footing in sharing and distribution of the Estate of the deceased. Some judgment as we shall see expressed the view that acknowledgement of the paternity of children born outside wedlock is against public policy as it emboldens promiscuity. The other and better view which tilts towards the provision of S 42(2) of the 1999 Constitution suggest that an innocent child should not be denied rights that ordinarily would have accrued to him if not for the actions of the parents. ${ }^{6}$ Chianu aligning with this better view had this to say:

In time Judges realized that there is no legal or moral justification to visit the sins of parents on innocent children. The ethical consideration of not punishing the innocent weighs against the objection based on presumed societal drive to ensure that sexual immorality is stemmed. ${ }^{7}$

In Cole v. Akinyele, ${ }^{8}$ the husband during the existence of a statutory marriage entered into an irregular relationship with the mother of the two Appellants. One of the Appellant was born during the existence of the statutory marriage between the husband and his wife, while the other was born a month and two weeks after the demise of the wife. The Court per Brett FJ held that it would be against public policy for a husband to father a child outside his marriage and consequently the first child cannot be legitimized even if the husband had publicly acknowledged his paternity under Customary Law before his demise.

Expressing his view on the decision of the Court to deny the $1^{\text {st }}$ Appellant the status of Legitimacy on ground of public policy Nwogugu opined that public policy will not be more outraged if the child born during the subsistence of the statutory marriage is legitimated by acknowledgement or the subsequent marriage of the parents under Customary Law. ${ }^{9}$ In Re Sarah Adadevoh, ${ }^{10}$ the deceased married his wife who predeceased him under the Marriage Ordinance with no issue. Upon his death, children from different women laid claims to the estate of the deceased. The trial Court held that since the children were illegitimate in accordance with English Law, they could not inherit. This decision was reversed by the West African Court of Appeal where it was held

\footnotetext{
${ }^{1}$ See S 8 Legitimacy Act, 1929. See also P.O, Itua, 'Legitimacy, Legitimation and Succession in Nigeria: Appraisal of Section 42(2) of the Constitution of the Federal Republic of Nigeria 1999 as amended on the Rights of Inheritance', Journal of Law and Conflict Resolution, 20124 (3), p. 33

${ }^{2}$ S 5(1), Legitimacy Act, 1929

${ }^{3}$ Ibid. S 5(2).

${ }^{4}$ Lawal v. Younan (1961) 1 ALL NLR 245; (1959) WNLR 155; (1961) NSCC 130

${ }^{5}$ Akin to the extant 42(2) of the 1999 Constitution.

${ }^{6}$ C.C.Ani (n.4) P.89

${ }^{7}$ E., Chianu, Law of Succession (Lagos; New System Press Limited, 2019) p.244.

${ }^{8}$ (1960) 5 FSC 84; (1960) SCNLR 192; (1960) NSCC 48.

${ }^{9}$ E.I, Nwogugu, Family Law in Nigeria. (Lagos: Heinemann,2001) Reprint p. 295. See also G.A, Agu, E.A, Odike, Modern Nigerian Family Law and Succession (Enugu: Renaissance Publishers Limited, 2005) p. 163.

${ }^{10}$ (1951) 13 WACA 804.
} 
that the legitimacy or otherwise of the children should be determined by the deceased's personal law. ${ }^{1}$ The Court, therefore remitted the question as to the status of legitimacy of the children to a lower Court. It was subsequently held by the Court that heard the reference that the children of the four women who were married under Customary Law were legitimate by birth but refused to grant the status of legitimacy to the other children of the concubines on grounds that it will offend public policy despite the fact that they were acknowledged. The trial Court in Alake v. Pratt, ${ }^{2}$ considered it contrary to public policy to place children born outside lawful wedlock on the same pedestal as legitimate children on basis of acknowledgement. The decision was however set aside on appeal by the appellate Court In Philips v. Osho, ${ }^{3}$ the legitimate children treated the Plaintiffs (who were born out of wedlock) as part and parcel of the family. They were also even given some properties and took part in decision making of the family. When dispute cropped in, the Plaintiffs relying on Ogun Modebe v. Thomas, ${ }^{4}$ made an ardent and forceful argument that based on the past relationships, the Defendants were estopped from denying their legitimacy and as such prayed the Court to order an account of all proceeds received as rent by the Defendants. Their claim was dismissed by the Supreme Court on ground of illegitimacy.

However, in Taylor v. Taylor, ${ }^{5}$ the three Plaintiffs were blood siblings born out of wedlock, two of them were born before their father married the Defendant under the Marriage Act. The Defendant conceded that her husband acknowledged the paternity of the Plaintiffs. For some 13 years after the death of their father intestate, the Defendant collected and appropriated the rent of the house that the estate left behind. In an action, the Plaintiffs sought for account of all the monies the Defendant received as rent. Coker J. held for them as the acknowledgement of paternity by their father ipso facto legitimized them and for the purpose of succession, the Defendant was awarded one third of the estate and the children were to share the remaining two thirds equally. It deserves mention that the party who intends to rely on proof of his paternity by acknowledgement is saddled with the task of proving that such acknowledgement took place. In Obasohan v. Obasohan, ${ }^{6}$ the failure of the Appellant to prove by concrete evidence that the deceased acknowledged his paternity ruptured his right of succession to the Igiogbe.

\subsection{Proof by Genetic Testing (DNA Test)}

A Deoxyribonucleic Acid (DNA) is the genetic material present in every cell of the human body and almost all other organisms. Virtually every cell within the human body has identical DNA. ${ }^{7}$ Even though the DNA pattern in the human genome between individuals are identical in over $99 \%$ of cases, a small number of differences are used to distinguish all humans; making each individual's genetic material unique except in cases of identical multiple births. ${ }^{8}$ These dissimilar patterns are utilized in DNA-based identity for parentage identification, resolution of immigration cases and criminal investigations. ${ }^{9}$ Parentage identification involves paternity and maternity testing. Whereas it is easy to identify the mother of a child only DNA testing can confirm paternity. DNA paternity testing remains the most reliable and precise type of paternity testing feasible. Every individual has two copies of genetic material; one is inherited from each biological parent. When the paternity of a child is under contention, a party is expected to present for genetic testing at the request of the opposing party. ${ }^{10}$ Various DNA sequencing, amplification, and testing techniques are currently in use with an accuracy rate of up to $99.99 \%$. Children can be tested at any age using umbilical cord blood specimen at birth, blood samples known as Restriction Fragment Length Polymorphism or buccal swab (or buccal scrap). ${ }^{11}$ If the DNA pattern between the child and the alleged father do not match on two or more DNA probes, then there is no genetic relationship between the two. ${ }^{12}$ If the DNA patterns between the child, mother and the alleged father match on every DNA probe, the likelihood of parenthood is $99.9 \%{ }^{13}$ In the Western world, this paternity testing has a significant legal implication when it comes to ascertaining child custody, provision of financial support and inheritance rights. ${ }^{14}$ The importance of DNA testing cannot be overemphasized as its use over the years has metamorphosed

\footnotetext{
${ }^{1}$ (1954) 14 WACA 116

2 (1955) 15 WACA 20.

3 (1973) ULR (P. 111) 316; (1972) 1 ALL NLR.

${ }^{4}$ FSC 357/1962 (Unreported).

${ }^{5}$ (1960) Lagos LR 286 cited in Chianu (n.36) p. 236.

${ }^{6}$ (2019) LPELR-47187 (CA).

National Library of Medicine (NLM). MedlinePlus Genetics. What is DNA? 2021.

https://medlineplus.gov/genetics/understanding/basics/dna/
${ }^{8}$ Saad R. Discovery, development, and current applications of DNA identity testing. Proc (Bayl Univ Med Cent). 2005;18(2):130-133. ${ }^{8}$ Saad R. Discovery, development, and
doi:10.1080/08998280.2005.1192805

${ }^{9}$ Ibid.

${ }^{10}$ FindLaw. Paternity Blood Tests and DNA. 2018. Available at: <https://www.findlaw.com/family/paternity/paternity-tests-blood-tests-anddna.html\#> Accessed on 10/4/2021 at 4:50 pm.

$11<$ https://family.Find Law.com/paternity/paternity-test-blood test and dna.html>. Accessed on 16 ${ }^{\text {th }}$ July, 2020 at 7: 46pm.Cited in C.C Ani (n.4).

${ }^{12}$ Ibid.

${ }^{13}$ Ibid.

${ }^{14}$ Schanfield, M.S. Deoxyribonucleic Acid | Parentage Testing. Editor(s): J. A. Siegel. Encyclopedia of Forensic Sciences, Elsevier. 2000;
} 
from a tool for determining paternity, resolution of some immigration issues to an instrument for solving crimes.

In Nigeria, there are increasing cases of absconding fathers who avoid parental responsibility by denying paternity. Also cases of spinsters who abdicates parental responsibility by dumping products of unwanted pregnancy by the roadside or in a ditch. ${ }^{1}$ DNA testing offer an accurate and confidential way of learning the facts because delaying finding out the truth increases the risk that a child could bond with someone who is not their father, causing emotional trauma to both parties if they eventually discover they are not related at a later date. Recently, a Judge of Delta State High Court has expressed the emotional trauma he passed through upon the discovery via DNA testing that he is not the biological father of three children from his marriage with his former wife. ${ }^{2}$ The pertinent question is, would it have amounted to injustice if the said Judge had instituted an action in Court challenging the paternity of the three children and instead of opting for genetic testing the Court adopted the legal presumption contained in Section 165 of the Evidence Act to ascertain the paternity? Secondly, would it not be a clear case of miscarriage of injustice if during the dissolution of marriage between the Judge and the wife, the Court mandates the Judge to pay certain sum of money as maintenance on the basis that the children being products of a valid marriage are deemed children of the man. It is without doubt that an application of DNA test at an earliest time would have saved the Judge both the emotional or psychological trauma he may experience at a later date.

\subsection{Attitude of Nigerian Courts toward the Use of DNA Testing in the Determination of Paternity}

Although the Nigerian Court recognizes DNA test as an acceptable way of establishing paternity, however, they are not amenable to the application of DNA testing. This may be attributed to the unceasing application of the highly reverenced presumption of law that a child born during the subsistence of a valid marriage is presumed a child of the man. Although the Court of Appeal in Ibeabuchi v. Ibeabuchi, ${ }^{3}$ agreed with the submission of Counsel for the Respondent that the paternity of a child can be determined by DNA Test, the Court however stated that DNA testing is not the only way to determine the paternity of a child. Furthermore, where the presumption as provided under S 165 of the Evidence Act can be applied successfully, there would be no need for DNA Testing. In a rather strange and odd facts of Anozia v. Nnanni \& Anor. ${ }^{4}$ the Appellant; a Legal Practitioner instituted the suit against the $1^{\text {st }}$ Respondent (who was at that time is a married woman) and the 57 year old $2^{\text {nd }}$ Respondent (the product of an alleged sexual relationship between the Appellant and the $1^{\text {st }}$ Respondent). The Appellant prayed the trial Court to order the $2^{\text {nd }}$ Respondent to subject himself to a DNA test in a bid to ascertain his paternity. Upon the refusal of his application, he appealed to the Court of Appeal. Although the Court agreed that DNA could be applicable and relevant where there is dispute as to the paternity of a child or where there is disputing claim or uncertainty as to the paternity of an individual, the Court nevertheless applied the presumption of law because it was common ground that at the point the purported sexual intercourse took place, the $1^{\text {st }}$ Respondent was validly married coupled with fact that the woman out rightly denied having sexual intercourse with the Appellant. The Court reinforced their decision by holding that the $2^{\text {nd }}$ Respondent is an adult and that the said application was intended by the Appellant to use the Court to prove his case and consequently the application was thrown out.

In the earlier cited Islamic case of Rabiu v. Amadu, ${ }^{5}$ although not bordered on the use of DNA testing to prove paternity, the Appellant in this case relied on a medical report which revealed that at the time the Appellant married the Respondent, she was already 20 - 22 weeks old pregnant. The Court of Appeal upheld the decision of the Upper Area Court that refused to act on the medical report. In resolving the issue as to whether expert evidence is used to determine paternity, the Court relied on Tabsiratu Al Hukkam Vol. 1 page 100 and stated that the opinion of an expert cannot be relied upon to ascertain paternity in relation to the children of a free woman but can be used to establish paternity in case of children of a slave woman, whose two masters had intercourse with her during the period of purity. The Court observed that since in the instant appeal there was no claim that the Respondent was a slave, there was therefore no need for any test to establish paternity. Finally, the Court held that since it was a delivery within wedlock and within the lawful period of gestation the legitimacy of the child would be presumed.

\subsection{Conclusion and Recommendations}

This paper analysed the application of the presumption of legitimacy in the determination of paternity of children and pointed out the hardships which strict application has caused in many occasions. It further considered other

Pages 504-515, <https://doi.org/10.1006/rwfs.2000.0472>. Accessed on 10/4/2021.

${ }^{1}$ E.A., Iyamu-Ojo, et al. 'Requirement to Consent to DNA Testing: A Case for Reform in Nigeria'. International Journal of Criminal and Forensic Science (2017) 1 (1), p. 11.

2 https://www.premiumtimesng.com/news/headlines/440030-dna-confirms-three-children-from-my-ex-wife-not-mine-judge.html. Accessed on $19^{\text {th }}$ April 2021 at 1:09 pm.

${ }^{3}$ Supra. (n.16).

4 (2015) LPELR-24277 (CA).

${ }^{5}$ Supra. (n.18). 
methods of ascertaining paternity especially as enumerated in Okolonwamu \& Anor. v. Okolonwanu \& Ors. ${ }^{I}$ The paper maintained that DNA testing is the most reliable method especially given the recent surge in paternity fraud cases and the ever improving DNA technology now saving many from the injustice arising from the presumption. Indeed, if DNA testing was employed in Okolonwamu \& Anor v Okolonwamu \& Ors, ${ }^{2}$ Rabiu $v$ Amadu, ${ }^{3}$ Ibeabuchi v. Ibeabuchi ${ }^{4}$ in ascertaining the paternity of the child, the Court may have arrived at a different conclusion. Thus, this paper advocates for a paradigm shift to the use of genetic testing by the Nigerian Courts as a conclusive proof of paternity which will obviously eliminate the psychological trauma experienced at a later date by both child and father upon the discovery that they don't share blood ties. It will also go a long way in curbing the increasing cases of extramarital affairs recorded in Nigerian homes which its devastating effect ranges from dissolution of marriage, domestic violence and the killing of a spouse by a partner.

\footnotetext{
${ }^{1}$ Supra. (n.21)

${ }^{2}$ Ibid.

${ }^{3}$ Supra. (n.18)

${ }^{4}$ Supra. (n.16).
} 